\title{
Social Networks as New Business Concept for Enterprises
}

\author{
Jelena Raut \\ Ph.D. student, University of Novi Sad, Faculty of Technical Sciences, Novi Sad-Kosančić Ivana 18, Republic of \\ Serbia, jelena.raut@yahoo.com \\ Slavica Mitrović \\ Ph.D., University of Novi Sad, Faculty of Technical Sciences, Republic of Serbia, mslavica@uns.ac.rs \\ Boban Melović \\ Ph.D., University of Montenegro, Faculty of Economics, Republic of Montenegro, bobanm@ac.me \\ Teodora Lolić \\ Ph.D. student, University of Novi Sad, Faculty of Technical Sciences, Republic of Serbia, teodora.lolic@uns.ac.rs
}

Received (14.06.2018.); Revised (30.08.2018.); Accepted (05.09.2018.)

\begin{abstract}
Social networks provide an excellent opportunity for internet advertising and promotion in order to improve business operations. The aim of this paper is to demonstrate the possibility of adequate use of social networks for the establishment, expansion and quality functioning of companies in the area of online trading. Subsequently, the paper presents a concept, a PHP-based web application, used by large trading systems, which is designed and adapted for use in small companies in their everyday operation. Finally, all measures for improving the existing system are presented using a specific case study, through integration with systems owned by company's permanent suppliers, in order to save time and increase the accuracy of procurement, which takes place on a weekly basis.
\end{abstract}

Key words: online trading, social networks, online shop, PHP application, web application, marketing, promotion

\section{INTRODUCTION}

Social networks are online communities that "draw together" people of similar interest. People usually perceive them as sites that gather people who know each other from real life, as in the case of Facebook. However, definition of social networks is much broader. Somehow, social networking began in 1995, with the famous classmaters.com, followed in 2003 by MySpace.com, which was the most popular site of the time, counting over 100 million members.

Afterwards, in 2006, Facebook arrives, and was very popular until 2014, when Instagram was created. Facebook is a commercial social network, founded by Mark Zuckerberg, a former Harvard student. At the very beginning, Facebook was intended only for students of Harvard University, enabling them to communicate and share information with each other. Later, many other universities, high schools and large companies begin to join Facebook.

Today, it has more than 800 million active users.

Mark Zuckerberg wrote Facemash, the predecessor of Facebook, while he was attending Harvard [1]. The original website resembled more to a game, in which photos were used to group users to couples, where users could select a person who was attractive to them with a single click [2]. Mark Zuckerberg created
Facebook while he was attending Harvard University. He did it by hacking the protected areas of the Harvard Network and copying private student identification photos. At that time, Harvard lacked the student version of Facebook (address book with basic information).

During the first four hours when it went online, Facemash attracted 450 visitors, with 22,000 views of photos [3].

The users quickly shared the site's domain with other students in the campus, but after several days it was shut down by Harvard administration.

Zuckerberg found himself in a situation before his expulsion from the University because administration accused him of violating copyright safety and privacy. In the end, however, the charges were dropped [4].

Afterwards, during the same semester, Zuckerberg expanded his original project by making it a learning aid for history of art, and posting 500 photos of Rome's history to the website, with each photo having the opportunity to be commented. He opened the website to his peers where students began to share their notes. The next semester, in January 2004, Zuckerberg started writing a code for the new website. As he claimed, he was inspired by the editorial of The Harvard Crimson, a student newspaper, on the Facemash incident [5]. 
On February 4, 2004, Zuckerberg launched The Facebook, at www.thefacebook.com [6].

Six days after launching the aforementioned site, three Harvard senior officers - Cameron Winklevoss, Tyler Winklevoss and Divya Narendra - accused Zuckerberg of deceiving them to help him create a social network named HarvardConnection.com, while using their ideas to make a parallel, competitive product. They turn to Harvard Crimson, after which the paper launches an investigation. They filed a lawsuit against Zuckerberg, which ended up with a settlement.

Initially, membership was restricted to Harvard students, and more than half of the students attending Harvard University registered in less than a month [7].

Eduardo Saverin, Dustin Moskovitz, Andrew McCollum and Chris Hughes join Zuckerberg to help promoting the site.

In March 2004, Facebook expanded to Stanford, Columbia and Yale.

After that, it expanded across other schools throughout the US and Canada.

In mid-2004, Sean Parker, an entrepreneur who unofficially advised Zuckerberg, became president of the company.

In June 2004, Facebook moves its headquarters to Palo Alto, California. The first investment came from PayPal founder, Peter Thiel. The company removed the determiner the from its name and acquires the domain www.facebook.com in 2005 for $\$ 200,000$ [8].

Facebook launched its secondary school version in September 2005, which Zuckerberg called a logical next step [9]. At that time, an invitation was needed in order to join Facebook.

Facebook later expanded its new member benefits to several companies, such as Apple Inc. and Microsoft [10].

On September 26, 2006, Facebook opened to anyone older than 13 with a valid e-mail address [11].

In 2007, Facebook had 100,000 business pages, allowing enterprises to attract potential clients and introduce themselves. They started as pages, but a new concept of enterprise sites was planned [12]. On October 24, 2007, Microsoft announced taking 1.6\% equity stake in Facebook worth \$240 million, which meant that the total value of Facebook at that time was $\$ 15$ billion [13].

In November 2008, Facebook announced opening an international headquarters in Dublin, Ireland.

In September 2009, Facebook announced a positive cash inflow for the first time [14].

In November 2010, shares were exchanged for private companies, where Facebook was worth $\$ 41$ billion at the time, making it the third-largest American company, trailing only Google and Amazon.

In March 2011, Facebook announced removing 20,000 profiles from its domain for various reasons, including spam, inappropriate content, and underage users [15].

In early 2011, Facebook announced that it plans to move its headquarters to Menlo Park, California [16]. DoubleClick has released statistics according to which Facebook reached a billion of views in June 2011, making it the most visited website ever. In March 2012,
Facebook launched the AppCenter, an online mobile store that sells applications that can connect on Facebook. The store was available on iPhone and other mobile networks.

YouTube is one of the first social networks which emerged at the same time when Facebook.

Twitter has been conceived as a social networking site and is great for anyone who wants to be briefly informed by people whom they know or respect.

The Flickr social network is customized to people who only want to upload their photos.

Last.fm internet radio is a music global social network.

Linkedln is a business-oriented social network, used mainly for business connectivity.

With the increasing use of Facebook and Instagram, people have realized that they are good advertisement platforms through which they can improve the sales of products they offer.

According to a study conducted by Universal Media, the following can be expected from the media by 2020. Five trends were identified:

1. The need for being connected everywhere. Wi$\mathrm{fi}$ is available everywhere and for everyone, allowing to do business from anywhere.

2. Media globalization instead of media localization. Today, the media becomes increasingly global. In the past, the media was national, but today the same media is known almost everywhere in the world.

3. The media is getting smarter. Being interconnected, they imitate reality through 3D technology.

4. Tendency towards virtual world. A world of virtual cloud memory is increasingly used in order to preserve necessary data.

5. Tendency towards individual-oriented advertising. Interconnecting the media enables to know at any time where the consumers are and to have real-time information - behaviourbased targeting will be the future norm.

For a large portion of businesses, the main role of Internet is either to reduce costs or add value to existing products, but also to create the opportunity to reach potential customers, which is a critical role [17].

A study conducted by Khalid Alrawi suggests that Internet advertising highly affects the quality of marketing. Managers believe that there are huge economic benefits from advertising on the Internet [18]. The concept is very simple. Everyone who has an account on a particular social network will at least once a day visit their account in order to see certain events. Having among his friends a company which advertises, there is a certain likelihood that the individual will decide to purchase.

Online trade allows sellers to save space and staff costs when it comes to a startup online store. However, social networks are a rapidly evolving concept, and people have the misconception that online stores have great savings in space and staff. Certain amounts of savings surely exist, however, if the company advances rapidly by using adequate advertising and proper 
market targeting, demands of the specific market will be rising on a daily basis, which requires more space (warehouse where the goods will be stored) and employees (receiving orders, packaging, updating the pages, and the like).

The positive side of online trade is in time related savings, since online shopping is much faster than serving customers in a traditional way. Online shopping also provides customers with time savings, given that they can order an item with one click, and the item will be delivered to their door. Moreover, customer choice increases, because they can order an item from any city or state online.

Proper management of corporate accounts on social networks is reflected in the quality of defined goals and expectations. Things to be considered when defining these goals are [19]:

- What is the desired effect of posting brands on social networks?

- Defining a budget for this type of advertising (note that this type of communication must be constant).

- Determining the communication channels, or which social networks will be used.

- Defining the desired communication tone and content type that will be shared on the network.

- Selecting and training the responsible person who will be the brand representative on the network.

- Finding the target group on social networks existing and potential users.

One of the most important steps in corporate social networking is finding the adequate target group of users, or targeting users on social networks [20].

This can be done in one of the following ways:

- $\quad$ Tracking keywords on Google. By monitoring keywords related to your organization, product or service on a daily basis, you will get useful information about what, who and how others speak about you or your products.

- $\quad$ Organizing prize games. Create an interesting game with clear and simple rules of participation and rewards on a given site that will be tailored to the target group. Welldesigned campaigns will attract both existing and potential customers / buyers.

- Posting advertisements on sites. Browsing popular sites and information that users leave on them in a detailed manner can help in finding a particular interest group. Facebook ads are one of the better ways of targeted advertising.

The next step in creating Facebook ads, in addition to targeting users, is naming the entire campaign and selecting the method of payment.

There are two methods of payment, depending on the ad delivery model, which are designed after Google ads:

1. CPC model (cost per click), determines the price to be paid each time someone clicks on your ad,
2. CPM model (cost per thousand impressions), pricing based on the number of people who saw your ad.

Each of the above models has its advantages and disadvantages, and it is necessary to carefully decide which model is the best suited to achieve the desired effect.

Daily budget represents the maximum amount of money you are willing to spend a day. This prevents the entire budget for the specific campaign from being spent too quickly.

Lifetime budget, on the other hand, represents the amount of money intended for spending for the entire campaign. One of its advantages is that it tries to optimize the ratio between the ad impression and user response.

Max bid is the maximum amount of money you are willing to pay per click or ad impression, depending on whether you choose the CPC or CPM model. This works by the principle of auction, which means that the market determines the price of your ad. If you target the most preferred group of users in the popular part of the day, the price of the ad will be close to the maximum bid.

Social media is the latest trend in modern marketing and significantly changes the way companies present themselves in the market. When engaging in social media, companies need to know that they have taken a step with no return. Regular education is needed, as well as tracking the trends and examples from practice in order to progress.

Proper management of corporate use of social media is reflected in defining possible goals in a qualitative and realistic way, e.g. at least a year of engagement without any effect; setting realistic expectations, e.g. you invest additionally in paid advertising as much as you get from social media; and budgeting efficiently the additional engagement of employees on the social media.

\section{DEVELOPMENT OF PHP WEB APPLICATIONS}

As it is well known, PHP is the successor to the PHP / $\mathrm{FI}$, created by Rasmus Lerford in 1994. This web application was initially used for tracking visits and is therefore given the name Personal Home Page Tools, abbreviated PHP Tools [21].

Over time, the existing web application needed a more diverse functionality and Rasmus writes a new PHP Tools which offered much richer content and wider implementation. The new model supported interaction with the database, creating a framework where users can develop simple dynamic web applications, such as book of impressions.

In June 1995, Rasmus releases a PHP source code and made it available to the public, giving developers the ability to use it, note the existing errors and improve it [22].

In September 1995, Rasmus advances the system once again, so the new application includes PHP functionality that we know today [23].

It had Perl scripts, automatic variable interpretation and HTML syntax. 
In October 1995, Rasmus releases a completely new code. April 1996 marks the beginning of the second generation of the PHP package, developed in $\mathrm{C}$ programming language, enabling users to develop simple dynamic web pages.

PHP Tools was hugely popular in the web development community. At the beginning of 1998, it had several thousand users worldwide. Starting from May 1998 and up to the end of the same year, about 60,000 domains containing PHP header have been registered, which means that it reached the number of approximately $1 \%$ of all domains at that time.

Despite these impressive figures, PHP Tools have seen limitations in their development.

Today, we know about 7 generations of PHP web applications.

The third PHP generation was a version that looked very much like the today's generation, created by Zeev Suraski and Andy Gutmans, where the project was based on $\mathrm{PHP} / \mathrm{FI}$, but was ultimately completely revised. PHP/FI had serious shortcomings and could not meet the needs of e-commerce. In collaboration with Ledorf, PHP 3.0, the successor of PHP/FI was published, and its further development was stopped [24].

The main feature of this version was its expandability, which attracted many developers around the world because they had the ability to add new features, and also introduced the possibility of object-oriented programming and higher consistency in the language syntax [25].

PHP 3.0 is a version officially released in June 1998, after 9 months of use in the trial phase. At the end of 1998, Zeev and Gutmans started rewriting $\mathrm{PHP}$, and their goal was to improve the core in order to enable working with larger applications.

The new core was called Zend engine, which was later followed by the introduction of Zend Technologies.

The new core appeared in public in mid-1999, and the version of PHP 4.0 was released in May 2000.

In addition to the clearly better performances, the new version also includes standard output caching, better web server support, more secure data transfer, and several new control structures.

PHP 5.0 arrives in July 2004, after a very long development period and several trial versions. It uses a Zeng 2.0 core, with a new object model and many new features, and has also brought a host of changes to object-oriented programming [26].

Version PHP 7.0 arrived in December 2015.

\subsection{Method of completion}

Although PHP can be used for developing console applications and graphical interfaces, its main use is in developing dynamic pages on the Internet.

Today, PHP is used by hundreds of thousands of developers and millions of sites, and this certainly includes some of the most visited sites in the world, such as Facebook, Wikipedia, YouTube and Flickr [36]. PHP based programs do not require translation; instead, they are interpreted in every execution. PHP interpreters can work according to the principle where the interpreter exists as an external application, which is launched to execute the given script every time it is requested by the user, and can also be installed as a web server mogul.

The second option, which is the most widely used today, provides a significantly higher execution speed, where the interpreter is always loaded into memory, so it does not have to refer to an external program.

Completion of a PHP script [27] :

- the client (an Internet user using an Internet browser) requests a PHP page from the server,

- the server forwards the request to the web service

- the web server recognizes that a PHP file is required,

- the web server recognizes that a PHP file is required,

- does not send its content to the client, but executes it as a program using a PHP module,

- $\quad$ the program output text is sent to the client as a result of the request,

- the client recognizes the type of result,

- the result is shown to the client in adequate manner.

\subsection{Program structure}

Similar to most scripting languages, PHP files contain a set of commands, executed successively, from the first to the last, where the last is also considered the end of the PHP program.

PHP files may contain the following types of elements [26] :

- HTML tags

- PHP tags,

- PHP commands,

- whites,

- commands.

\section{PHP tags}

There are four styles for writing PHP tags :

- HML style, using the <?php and ?> delimiters. Such style is recommended, and is required when the PHP code is embedded in the HTML code.

- $\quad$ The shortened <? and ? > delimiter can be used by activating the short_open_tag in the php.ini configuration file, but its use is not recommended because it is not supported in some environments.

- The script style using the <script language="php" > and </ script $>$ delimiters is a longer version of the HML style and is usually recommended when other scripting languages are used at the same time, especially if HTML editors make problems.

- $\quad$ The ASP style using the $<\%$ and $\%>$ delimiters represents another shortened version, and is the most commonly used in ASP and ASP.NET environments, but it is necessary to enable the short_open_tag option in the php.ini configuration file. 
A new strategy for application software companies is to allow access to web software that has been previously distributed as a local community.

Depending on the type of application, completely different browser-based interfaces can be developed or existing applications can be customized to use different presentation techniques.

\section{A CASE STUDY FOR THE DEVELOPMENT OF AN INTERNAL PHP APPLICATION TO IMPROVE THE QUALITY OF SALE}

In order to arrive to the final result, i.e. PHP web application, which will be discussed later, the company needed 7 months of preparation. This do not relates to the actual implementation of the site, but the entire process which was required to come to the idea, which is eventually implemented.

At the beginning, the company lacked any system that would track items in the inventory. Everything went down to the daily communication between the warehouse and the seller.

In that sense, the seller, or any employee of the company, who communicates with dozens of buyers each day, had to call the warehouse, describe the model that the customer wanted, and check whether it is available in the inventory in the required size.

There are two problems already in here - the first is ITEM DESCRIPTION, where a huge number of errors occur. A subjective description of the item that unfolds between the seller and the warehouse can lead to a problem in which the warehouse person fails to understand the seller regarding the item and does not check the desired item at all. Consequently, the warehouse sends the seller incorrect information (that the item is available or not in the required size), and the incorrect information comes to the buyer. For example, the customer decides to buy, and receives a wrong item. Replacing the wrong item induces costs for the company. Apart from the huge waste of time spent on the communication between the warehouse and the seller, time is consumed also as a result of replacement and retention of the item that could have been sold to a person who wants it, but the company does not have it in the inventory.

This was the crucial problem of this company, and the solution is extremely simple - introducing codes for the items and arranging the warehouse.

This process took approximately 10 days.

Each item was given a specific code which was also indicated on each box containing the item, as well on the warehouse room containing the box, for example 20-75 (items with codes 20 to 75 are located in Room 2). The following problem occurred: all this information was stored in an Excel sheet with data on the amount of each item in the inventory.

This did not cause significant cost-related problems to the company. The solution certainly enabled saving a specific amount of time, but the problem persisted.

The table has been updated every day after working hours. Despite the assumption that the staff, after the working hours, updated the table accurately in terms of removing the items that were delivered that day (the assumption is incorrect because the entire inventory was completely revised on every second week, the revision has taken about 20 hours, and this lead to the fact that the inventory was incorrectly updated every day), we still have the above problem.

It takes only a single purchase order and removing a single item, and the table of that day is no longer accurate because the item is packed to the buyer, and will not be removed from the inventory and the table until the end of the working day.

A better solution was needed, an inventory that would be accurate at all times and that would provide accurate information to every person in the company.

The solution was a small internal site that would be available to every person in the company.

The web application was not immediately fully formed, it is constantly improving and is not yet completed for a simple reason that ideas are evolving on a daily basis, but importantly, today it performs very well and does not impair the quality of work.

The functioning of the employee account will be discussed next.

INVENTORY is everything.

It is a great advantage of this system that the inventory was updated in detail before entering it in the web application, and since then it was no longer necessary to do any inventory list.

It is only required to amend the existing model from the central account and enter new codes for new models that the company imports.

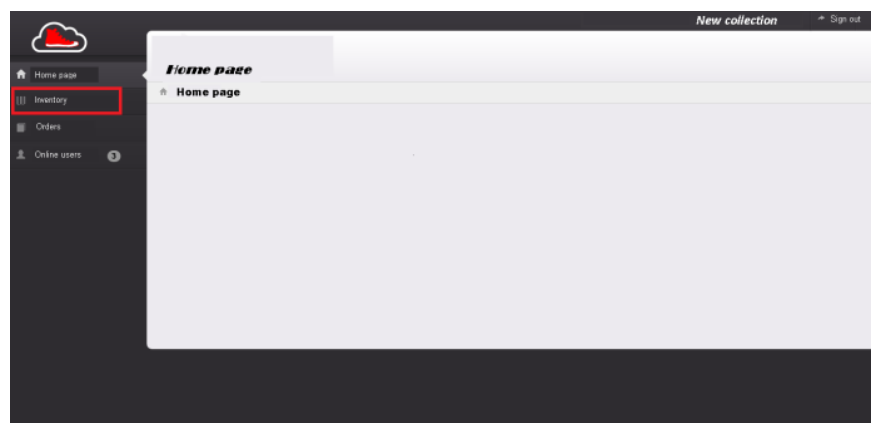

Figure 1. Home page of the web application on the employee account in the company

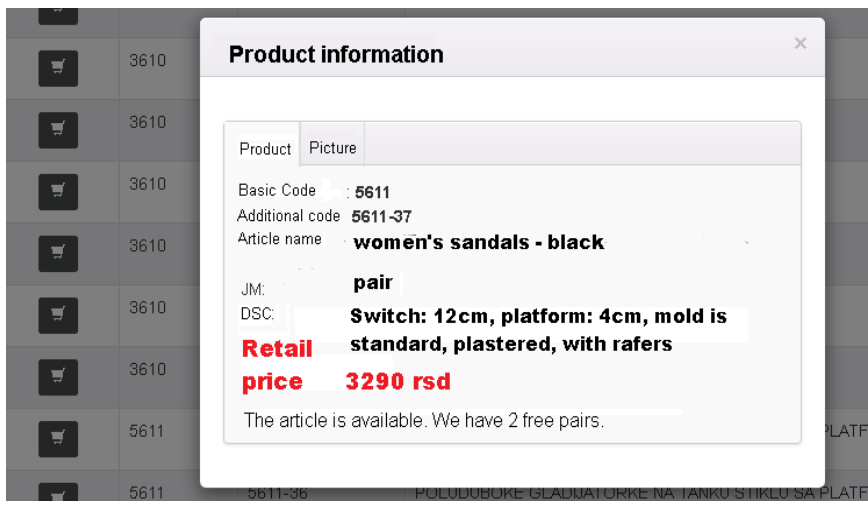

Figure 2. Access to the item encoder, where the available inventory can be checked, and see the detailed description and the photo of the requested item 
By clicking the code tab and selecting a code, one can see the availability of an item at any time, its detailed description and photo, so that all necessary information on the item is available.

Next is the description of the improvement of workflow by using the web application.

The inventory worked perfectly and continues to do so, and until it was not introduced, the employees were not aware of the amount of time that was consumed by manual work.

There was another very big problem.

Thus, each seller has his own separate account. Once he makes the order form and saves it in his account, the order form goes to the account of the person in charge of packaging - the order is given the status that it is prepared, then it is sent, billed or returned.

With the time saved on communication, sellers could now receive a larger number of orders, but now a problem occurs in the warehouse.

Orders are received until 12, that is during four working hours, and from 12 to 16 people are preparing the packages in the warehouse. This is a job where time cannot be reduced, but the printing of addresses and the possibility of erroneous data entering is still a big problem, as it was previously.

The next idea is integrating with the courier service system.

Connecting all the information about addresses in the whole territory of Serbia was a success, which facilitated the work of sales people.

Adding a customer

\begin{tabular}{|c|c|}
\hline Name and surna & JELENA RAUT \\
\hline Country & SREIJA \\
\hline City & NOVI SAD \\
\hline Municipalities & NOVI SAD \\
\hline \multirow[t]{8}{*}{ Address } & KOS \\
\hline & DEŽEA KOSTOLANJIJA \\
\hline & JOVANA KOSOVCA \\
\hline & KOSANČIĆ IVANA \\
\hline & KOSMAJSKA \\
\hline & KOSOVSKA \\
\hline & KOSTE ABRAŠEVIĆA \\
\hline & KOSTE HADŽI MLAEEG \\
\hline
\end{tabular}

Figure 3. Creating a purchase order (filling customer data)

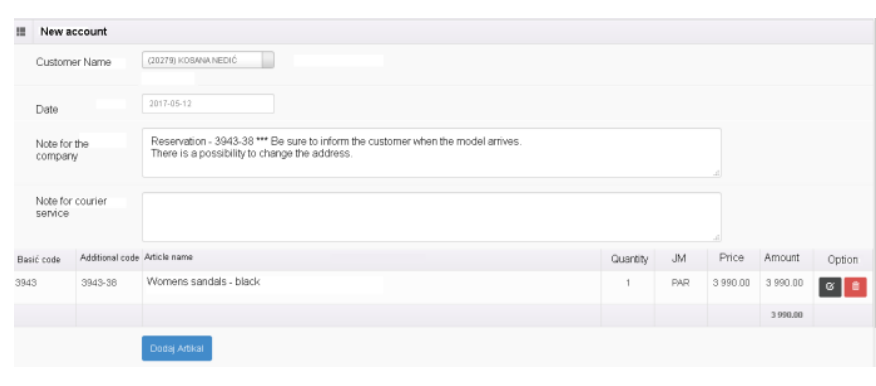

Figure 4. Complete order form (with the selected item)

However, this is not the greatest advantage of this integration.

After this step, when the buyer was recorded with the item he ordered, the job of the person in the warehouse is to pack the item and write the number of the assigned order. Based on that number, the courier service prints the address and attaches it to the package.

Time saving is enormous. Another benefit of this step is the creation of a customer database and sending notifications through applications that allow sending SMS messages to a particular phone base. The company used this benefit to inform buyers about current seasonal sales, which immediately increased the turnover.

These are the main benefits that the company achieved by making an internal web application, which turned out to be important for its good and accurate functioning.

\section{CONCLUSION}

Benefits from this site include the reduced time spent on calculating employee earning. If, for example, the employee earns $10 \%$ from the sale of each item, there is a card on the central account that records every billed item. At the moment the item is collected, the earning increases.

Further benefits include:

- monitoring the efficiency of each employee,

- monitoring the monthly turnover and profits of the company,

- monitoring the trend of demand for a specific item, based on which inventories of the most wanted models are refilled,

- monitoring people who order the most items at monthly, quarterly and semi-annual basis and granting them incentives for future purchases,

- monitoring the number of complaints and the reasons for their occurrence, enabling the company to correct these mistakes in the future.

There are a huge number of benefits from introducing such a system in the company.

Of course, this is not the end when it comes to further improvement of the web application, because almost all problems within the company are solved, except for problems with suppliers.

One of the main problems is that all procurement unfolds through direct communication. In addition to the linguistic barrier arising from the fact that some suppliers do not speak English, there is also a problem that very often not all models ordered by the company are delivered; sometimes they are not delivered in 
quantities ordered, or certain items are stolen before they arrive to the company, etc. Therefore, there are many unsolved problems.At least part of these problems can be resolved by implementing a very simple system by suppliers. It is important for the company to integrate this supplier system with the above described system.

The idea is that the supplier creates an internal web application, similar to the one described above, and that the procurement of the company works according to the same principle as the regular purchase.

\section{ACKNOWLEDGMENTS}

The work was made within the project of the Ministry of Education, Science and Technology Development, the project Transformation of Social Identity in Serbia in the Crisis and its Impact on European Integration, project number ON-179052.

\section{REFERENCES}

[1] Locke, L. (2007), "The Future of Facebook", available at: http://content.time.com/time/business/article/0,8599,1644040,00. html (accessed: 08.01.2018.)

[2] Tabak Alan, J. (2004), "Hundreds Register for New Facebook Website", The Harvard Crimson, Cambridge, available at: https://www.theatlantic.com/technology/archive/2011/11/markzuckerbergs-harvard-career-according-crimson/335956/ (accessed: 29.11.2017.)

[3] McGirt, E. (2007), "Facebook's Mark Zuckerberg: Hacker. Dropout. CEO", available at: https://www.fastcompany.com/59441/facebooks-markzuckerberg-hacker-dropout-ceo (accessed: 03.02.2018.)

[4] Fayaz Ahmad, N. and ShakeelAmdah, S. (2014), "Facebook and Its Usage Pattern and Case Study od Students at Central University of Kashmir", Journal od Business and Management Science, Vol. 2, No. 1, pp. 21-25

[5] Hoffman, C. (2008), The Battle for Facebook, Rolling Stone, New York

[6] Seward Zachary, M. (2007), "Judge Expresses Skepticism About Facebook Lawsuit",The Wall Street Journal, Vol. 3, No. 2, pp 3-9

[7] Phillips, S. (2007), "A brief history of Facebook", available at https://www.theguardian.com/technology/2007/jul/25/media.new media (accessed: 21.01.2018.)

[8] Williams, C. (2007), "Facebook wins Manx battle for facebook.com", available at http://www.theregister.co.uk/2007/10/01/facebook_domain_dispu te/ (accessed: 15.02.2018.)
[9] Fowler Geoffrey, A. (2012), "Facebook Billion and Counting", The Wall Street Journal, Vo. 5, No. 4, pp. 14-19

[10] Kirk, P. (2011), The facebook effect - the inside story of the company that is connecting the world, Simon and Schuster, New York

[11] Barker, M., Barker, D., Bormann., N. and Neher, K. (2013), Social Meadia Marketing, Mason, Ohio

[12] Richmand, R. (2007), "Enterprise: Facebook, a Marketer's Friend; Site Offers Platform To Tout Products, Interact With Users", Wall Street Journal, Vol. 3, No. 2, pp. 21-23

[13] Hoefflinger, M. (2017), Becoming Facebook: the 10 challenges that defined the company that disrupting the world, Hardcover, New York

[14] Rouhianinen, L. (2016), 101 Facebook marketing tips and strategies for small businesses, Kindle edition, New York

[15] Uttar, P. (2011), "Facebook deletes 20,000 underage profiles daily", $\quad$ available at: https://www.huffingtonpost.com/2011/03/23/facebook-underageusers_n_839437.html, (accessed: 26.10.2017.)

[16] Parr, B. (2011), "These Are Facebook's New Offices ", Mashable, New York

[17] Mirković, M., Vrgović, P., Ćulibrk, D., Stefanović, D. and Anderla, A., (2014), Evaluating the Role of Content in Subjective Video Quality Assessment, The Scientific World Journal, vol. 2014, Article ID 625219, 9 pages, 2014. doi:10.1155/2014/625219

[18] Khalid, A.. (2009), "Advertiser perception of the internet as a marketing communication vehicle: case study", African Journal of Marketing Management, Vol.1(2), pp. 062-069

[19] Grogan, R. (2013), "10 examples of facebookd ads that actually work (and why) ", available at: https://blog.hubspot.com/blog/tabid/6307/bid/33319/10examples-of-facebook-ads-that-actually-work-andwhy.aspx\#sm.00001uanod47c5d34sjy7ug114ngt, (accessed: 03.03.2018)

[20] Walsh, K. (2015), How to Reach your Taget Market on Facebook, 360 Entrepeneur, Social Media Marketing, New York

[21] Ullman, L. (2011), PHP for the Web, Kindle, San Francisco

[22] Lerdorf, R. (2002), "PHP's design goal from the very beginning is very simple. To solve the common web problem. That's it.", Advogato, Article 470

[23] Nixon, R. (2018), Learning PHP, MySQL and Java Script, O Really Media, United States of America

[24] Pierre, J. (2017), "PHP programming", availbale at: https://secure.php.net/archive/2016.php\#id2016-11-10-1, (accessed: 07.05.2017.)

[25] Atkinson, L. and Suraski., Z. (2004.), Core PHP Programming, Prentice Hall Professional, New York

[26] Lurig., M (2008), PHP Reference: Beginner to Intermediate PHP5, Kindle book

[27] Davis Michele, E and Phillips, Jon A. (2007), Learning PHP \& MySQL: Step-by-Step Guide to Creating Database-Driven Web Sites, O'Reilly Media, Inc.

[28] Viling, L. and Tomson, L., (2009) PHP and MySoul - razvoj aplikacija za web, Mikroknjiga, Beograd

\title{
Društvene mreže kao novi concept poslovanja preduzeća
}

\author{
Jelena Raut, Slavica Mitrović, Boban Melović, Teodora Lolić
}

Primljen (14.06.2018.); Recenziran (30.08.2018.); Prihvaćen (05.09.2018.)

\section{Apstrakt}

Društvene mreže pružaju odličnu priliku za oglašavanje i promociju, u cilju poboljšanja kvaliteta poslovanja. Cilj ovog rada je da se demonstrira mogućnost adekvatne upotrebe društvenih mreža za uspostavljanje, proširenje i kvalitetno funkcionisanje preduzeća, u oblasti elektronske trgovine. Kasnije, u radu je predstavljane koncept, koji je baziran na PHP-web aplikaciji, koju koriste veliki trgovački sistemi, a koji je dizajniran i prilagođen za korišćenje u manjim kompanijama, kao pomoć u njihovom svakodnevnom radu. Na kraju, sve mere za poboljšanje postojećeg sistema su prezentovane korišćenjem specifične studije slučaja, kroz integraciju sa sistemima, u vlasništvu stalnih dobavljača kompanije.

Ključne reči: online trgovina, društvene mreže, online prodavnica, PHP aplikacija, web aplikacija, marketing, promocija 